\title{
КОМУНИКОЛОГИЈА КАО НАСТАВНА ДИСЦИПЛИНА У СТУДИЈСКОМ ПРОГРАМУ ЗА РАЗРЕДНУ НАСТАВУ - ПОТРЕБА И ЗНАЧАЈ ${ }^{1}$
}

\author{
Живорад Миленовић ${ }^{2}$ \\ Универзитет у Приштини - Косовској Митровици, Учитељски факултет \\ Марија Миленовић ${ }^{3}$ \\ Универзитет у Нишу, Филозофски факултет, Департман за комуникологију и \\ новинарство \\ Јелена Седларевић ${ }^{4}$ \\ Основна школа Радмила Шишковић у Смедеревској Паланци
}

\begin{abstract}
Ancmpaкm: Проблем истраживања је потреба и значај учења комуникологије као наставне дисциплине на студијама за разредну наставу, који се у раду теоријски проучава из угла универзитетске наставе, студија за комуникологију и рефлексивне праксе учитеља и на емпиријском нивоу на основу перцепције студената разредне
\end{abstract}

\footnotetext{
${ }^{1}$ Рад је настао као резултат у оквиру четири научна пројеката: 1) Имплементација наставних садржаја из Дидактике у студијске програме за васпитаче у предиколским установама у измененим условима предиколског васпитана и учена (ИНСД-СПВУ-ИУПВУ), који у периоду 2021-2022. финансијски подржава Министарство просвете, науке и технолошког развоја Републике Србије, у оквиру пројеката из програмских активности Министарства просвете, науке и технолошког развоја Републике Србије Развој високог образована у 2021; 2) Доипринос докторских студија разредне наставе матичности факултета за образоване учитель: стане, дилеме и перспективе методике разредне наставе, евиденциони број ИЈП 001, који у периоду од 1. 7. 2021-31. 12. 2022, финансијски подржава и реализује Учитељски факултет у Призрену - Лепосавићу, Универзитета у Приштини - Косовској Митровици; 3) Израда софтввера за проијениване даровитости код ученика, евиденциони број 19/6-020/961-26/18, који у периоду 10. 1. 2019, с датумом завршетка у 2021. 1. 10. 2015, финансијски подржава Министарство за научно-технолошки развој, високо образовање и информационо друштво Републике Српске, a реализује Педагошки факултет у Бијељини, Универзитета у Источном Сарајеву, Босна и Херцеговина - Република Српска; и 4) Софтвверска подрика за предвиђаюе успјешности студирағь, евиденциони број 19/6-020/961-27/18, који у периоду 10. 1.2019, с датумом завршетка у 2021. 1. 10. 2015, финансијски подржава Министарство за научно-технолошки развој, високо образовање и информационо друштво Републике Српске, а реализује Педагошки факултет у Бијељини, Универзитета у Источном Сарајеву, Босна и Херцеговина - Република Српска.

${ }^{2}$ zivorad.milenovic@pr.ac.rs

${ }_{3}^{3}$ marija.milenovic13@gmail.com

${ }^{4}$ jelenasedlarevic@oshrs.edu.rs
} 
наставе. У истраживању се пошло од опште претпоставке да су садржаји из комуникологије значајни за обављање учитељске професије, али да се недовољно изучава на студијама за разредну наставу. Пошло се и од посебних претпоставки да ће истраживањем бити издвојени фактори који указују на значај учења садржаја из комуникологије на студијама за разредну наставу и да ће бити утврђено да не постоји значајна разлика у проценама студената разредне наставе о значају и потреби учења садржаја из комуникологије на студијама за разредну наставу у зависности од уписане године студија. Да би се то утврдило, у октобру 2021, на узорку од 108 студената Студијског програма за разредну наставу на Учитељском факултету у Призрену - Лепосавићу, спроведено је истраживање приказано у овом раду. Подаци прикупљени Скалером КНД-СРН (〈=0,845), обрађени су факторском анализом и анализом варијансе. Факторском анализом су издвојена три фактора: 1) различитост садржаја, 2) значај учења и 3) потреба учења садржаја из комуникологије на студијама за разредну наставу. Анализом варијансе је утврђено да не постоји значајна разлика у проценама студената разредне наставе о значају и потреби учења садржаја из комуникологије на студијама за разредну наставу у зависности од уписане године студија. На основу теоријско-емпиријског проучавања је утврђено да су наставни садржаји из комуникологије значајни за будуће учитеље, да су различито заступљени на студијским програмима за разредну наставу у Републици Србији, да су студенти углавном сагласни у проценама о потреби и значају комуникологије на студијама за разредну наставу, што указује на потребу измене и допуне студијских програма за разредну наставу наставним садржајима из комуникологије и потребу професионалног усавршавања учитеља у циљу стицања неопходних знања из комуникологије.

Кључне речи: учитељска професија, учитељ, комуникаиија у разредној настави, соиијално-комуникацијске компетенције, јасно и гласно изражавање, квалитетно слушање.

\section{Увод}

Облици преношења порука и информација међу људима (између две особе, у мањим и већим групама људи, унутар организације и на друге начине) предмет су проучавања многих наука и њихових дисциплина: језика, социологије, психологије, педагогије и осталих наука. Поред вербалне комуникације, постоји и невербална комуникација, како у свакодневном животу, тако и у различитим областима друштвене делатности (Миленовић и сар., 2014). Комуникација се одвија и путем различитих медија и информационо-комуникационим технологијама (Ћитић, 2020; Тривић, 2019). Последњих се година указује на значај повезаности новинарства и комуникологије као једног од видова вишег нивоа комуникологије (Мирков, 2019). У овом раду, комуникологија се проучава са аспекта њеног значаја и потребе као наставне дисциплине на студијама за разредну наставу. На овим студијама се припремају будући учитељи, који поред стручног знања из различитих научних области и њихових дисциплина, треба да стекну и оптималне педагошко-психо- 
лошке компетенције (Миленовић, 2010), дидактичко-методичке компетенције (Миленовић, 2009) и социјално-комуникацијске компетенције (Миленовић и Јефтовић, 2013). Ове последње, поред способности учитеља за рад у тиму и поштовање различитости међу људима, подразумевају и вештине и способност учитеља за јасним и гласним изражавањем и квалитетним слушањем (Ивковић и Миленовић, 2014). Све то указује, да је комуникологија као наставна дисциплина значајна за будуће учитеље, што указује на потребу да се утврди у којој мери је комуникологија заступљена на студијама за разредну наставу.

Критичком анализом научних извора из области комуникологије (Kohen \& Dori, 2019; Harel \& McAllister, 2019) може се закључити да су расправе о суштини комуникације, начинима комуникације и уопште о потреби и значају комуникације старе колико и само људско друштво. Без обзира на то, комуникологија као наука је новијег датума, па се и при расправи о историјској димензији комуникологије прилази са аспекта проучавања проблема у области комуникологије који су новијег датума и који изражавају битно другачије приступе потреби и значају комуникологије (Јеленковић,2013). Може се рећи и да се савремена комуникологија појавила са појавом мас-медија, који се, и као такви стално мењају и осавремењују. Све то захтева и битно другачији приступ комуникологији. Она данас постаје значајна дисциплина и у избору професије (Јеленковић и Јеленковић, 2013). На тим основа се темељи и проучавање њене потребе и значаја на студијским програмима за образовање учитеља.

Анализом студијских програма за разредну наставу на свим факултетима у Републици Србији, на којима се школују будући учитељи, може се видети да комуникологија као наставни предмет не постоји. Анализирани су актуелни програми. На већини ових факултета, постоје тангентни наставни предмети, углавном изборног карактера, у оквиру којих студенти уче неке од наставних садржаја који су повезани са комуникологијом. Изузетак је Учитељски факултет у Београду. Анализом Студијског програма за образовање учитеља, Учитељског факултета у Београду из 2015. и Студијског плана и програма дипломских мастер студија за образовање учитеља, Учитељског факултета у Београду из 2015, може се утврдити да они не садрже ниједан наставни предмет који је повезан са комуникологијом.

На осталим факултетима, по питању заступљености комуникологије у студијским програмима за разредну наставу, ситуација је различита. Углавном не постоји довољна заступљеност наставних садржаја из комуникологије, већ су заступљени наставни садржаји из сродних, односно научних области. На Учитељском факултету у Призрену - Лепосавићу, на основним академским студијама за разредну наставу, студенти слушају наставу на другој години студија која је предвиђена за наставни предмет Облици изражавања, који је у статусу изборног предмета. На четвртој години студија је предвиђен наставни предмет Основи комуникащије и вођење у школи, који је такође изборног карактера (Студијски програм основних академских студија Разредна настава, 2021). На мастер академским студијама за разредну наставу на Учитељском факултету у Призрену - Лепосавићу не постоји ниједан наставни предмет у оквиру кога се уче наставни садржаји из комуникологије (Студијски програм мастер академских студија Разредна настава, 2021). 
Слична је ситуација и на Педагошком факултету у Врању. На основним академским студијама за разредну наставу, студенти у другој години студија слушају наставу из наставног предмета Облици изражавањ а са стилистиком који је изборног карактера и на трећој години студија из наставног предмета Методе комуникологије који је такође изборног карактера (Студијски програм за образовағе учитеља, 2015). На мастер академским студијама за разредну наставу на Педагошком факултету у Врању нема наставних предмета у оквиру којих се уче наставни садржаји из комуникологије (Мастер академске студије за образовање учитеља, 2015).

На Педагошком факултету у Јагодини, на основним академским студијама за разредну наставу студенти на првој години студија слушају наставу из наставног предмета Говорне вештине и комуникација и Интеракција и комуникаųија у васпитном раду, који су изборног карактера, и на другој години студија из наставног предмета Реторика, који је такође изборног карактера (Основне академске студије, Учитељ, 2021). На мастер академским студијама за разредну наставу на Педагошком факултету у Јагодини нема ниједног наставног предмета у оквиру кога се уче садржаји из комуникологије.

На Педагошком факултету у Ужицу, на основним академским студијама за разредну наставу, студенти у првој години студија слушају наставу из наставног предмета Медији и комуникације који је изборног карактера и на другој години студија из наставног предмета Психологија комуникащије који је такође изборног карактера (Студијски програм основних академских студија Учиmељ, 2019). На мастер академским студијама за разредну наставу на Педагошком факултету у Ужицу не постоји ниједан наставни предмет у оквиру кога се изучавају наставни садржаји из области комуникологије (Студијски програм мастер академских студија Учитељ, 2019).

На Педагошком факултету у Сомбору, на основним академским студијама за разредну наставу студенти не слушају наставу из области комуникологије (Студијски програм основних академских студија Дилопмирани учитељ, 2013). На мастер академским студијама слушају наставу из наставног предмета Облици и видови остваривања комуникације, који је изборног карактера (Сmyдијски програм Мастер учитељ, 2013).

Изузетак од свих факултета у Републици Србији на којима се образују будући учитељи је Учитељски факултет на мађарском наставном језику у Суботици који једини на основним академским студијама за разредну наставу има обавезни предмет из кога се слушају садржаји повезани са садржајима из комуникологије. Ради се о наставном предмету Култура говора на другој години студија. Поред поменутог предмета, студенти на другој години студија слушају и наставу из наставних предмета Развој комуникаиијских компетенција страног језика (енглески и немачки), који је изборног карактера (Студијски програм OAC1 - Дипломирани учитељ, 2014). На мастер академским студијама за разредну наставу на Учитељском факултету на мађарском наставном језику у Суботици нема наставних предмета у оквиру којих се слуша настава повезана с комуникологијом (Студијски програм МАC1 - Мастер учитељ, 2014).

Наставу из наведених наставних предмета углавном реализују универ- 
зитетски наставници који су из области језика и књижевности, психологије и социологије. Полазећи од иницијалних усмерења предметних наставника, реално је очекивати да је и настава темељена на проблему и предмету проучавања поменутих наука и њихових дисциплина. То је недовољно за свеобухватно схватање и разумевање комуникологије која није само наука о преношењу порука (Balser et al., 2017; VanDerveer, 2017). Добро познавање основа комуникологије од значаја је за обављање било које друштвене делатности.

\section{Метод}

Циљ истраживања је да се идентификују процене студената разредне наставе о потреби и значају учења садржаја из комуникологије на студијама за разредну наставу. У истраживању се пошло од опште претпоставке да су садржаји из комуникологије значајни за обављање учитељске професије, али да се недовољно уче на студијама за разредну наставу. Пошло се и од посебних претпоставки да ће истраживањем бити издвојени фактори који указују на значај учења садржаја из комуникологије на студијама за разредну наставу и да ће бити утврђено да не постоји значајна разлика у проценама студената разредне наставе о значају и потреби учења комуникологије на студијама за разредну наставу у зависности од уписане године студија. Да би се то утврдило, у октобру 2021, на узорку од 108 студената Студијског програма за разредну наставу Учитељског факултета у Призрену - Лепосавићу, спроведено је истраживање приказано у овом раду. Према уписаној години студија, структура узорка је следећа: I година студија - 9 (8,30\%); II - 26 (24,10\%); III - 50 (46,30\%); IV - 23 (21,30\%).

Коришћене су следеће методе: метода анализе садржаја, дескриптивна, трансферзална и компаративна метода. Примењене су истраживачке технике анкетирање и скалирање. Подаци су прикупљени Скалом процена студената разредне наставе о значају и потреби учења садржаја из комуникологије на студијама за разредну наставу (Скалер - КНД-СРН). Скалер је конструисан за ово истраживање. На самом истраживању провераване су неке метријске карактеристике скалера и извршена његова корекција. Скалер је Ликертовог типа. Састојао се од 15 ајтема с тростепеном скалом интензитета сагласности - 1) слажем се, 2) нисам сигуран - и 3) не слажем се. Након корекције и изостављања 3 ајтема (ајтеми 2, 3 и 4 из првобитног скалера), за тумачење резултата факторске анализе и рачунање скора за сваки ајтем за тумачење резултата добијених анализом варијансе, остало је 12 ајтема.

Табела 1. КМО, Бартлетов тест сферичности и Кронбахов алфа коефицијент

\begin{tabular}{llr}
\hline КМО & & 0,614 \\
\hline \multirow{2}{*}{ Бартлетов тест } & $\chi^{2}$ & 393,806 \\
сферичности & $\mathrm{df}$ & 66 \\
& $\mathrm{p}$ & 0.000 \\
\hline & \langle & 0,845 \\
\hline
\end{tabular}


Кајзер-Мејер-Олкинов тест показао довољну вредност $(\mathrm{KMO}=0,614)$. Бартлетов тест сферичности је достигао статистичку значајност на нивоу 0,001 $(\mathrm{p}=0,000)$, што указује на факторабилност матрице, њену прилагођеност узорку истраживања и оправданости факторске анализе. Поузданост инструмента испитивана је Кронбаховим алфа коефицијентом који је показао врло добру вредност $(\langle=0,845)$ (Табела 1$)$.

Табела 2. Комуналитети (h)

\begin{tabular}{ccccccccccccc}
\hline Ајтеми & 1 & 2 & 3 & 4 & 5 & 6 & 7 & 8 & 9 & 10 & 11 & 12 \\
\hline $\mathrm{h}$ & 0,654 & 0,347 & 0,319 & 0,475 & 0,513 & 0,768 & 0,481 & 0,815 & 0,592 & 0,805 & 0,486 & 0,730 \\
\hline
\end{tabular}

Задовољен је Општи Тостенов критеријум. Све вредности комуналитета су веће од 0,30 и имају вредности од $\mathrm{h}=0,319$ код трећег ајтема, до $\mathrm{h}=0,815$ код осмог ајтема (Табела 2).

Подаци прикупљени истраживањем обрађени су у статистичком програмy IBM SPSS 24.0, применом статистичких поступака: факторска анализа с Варимакс ротацијом и анализа варијансе. Резултати истраживања приказани су табелама и дијаграмима.

\section{Резултати}

Подаци прикупљени истраживањем, најпре су били подвргнути анализи главних компоненти факторском анализом с Варимакс ротацијом.

Табела 3. Карактеристични коренови и \% укупно објашњене варијансе након Вари-

\begin{tabular}{cccc}
\multicolumn{3}{c}{ макс ротащије } \\
\hline \multirow{2}{*}{ Компоненте } & $\begin{array}{c}\text { Карактеристични } \\
\text { корен }\end{array}$ & $\begin{array}{c}\text { \% објашњене } \\
\text { варијансе }\end{array}$ & $\begin{array}{c}\text { Кумулативни \% } \\
\text { објашњене варијансе }\end{array}$ \\
\hline 1. & 2,609 & 21,740 & 21,740 \\
2. & 2,183 & 18,192 & 39,932 \\
3. & 1,692 & 14,099 & 54,031 \\
\hline
\end{tabular}

Гутман-Кајзеровим критеријумом издвојене су три компоненте с карактеристичним кореновима већим од један, које укупно објашњавају 54,031\% заједничке варијансе (Табела 3).

Анализом Дијаграма 1 може се уочити да постоје најизразитији преломи код 7. и 10. фактора, али и код 4. фактора. Без обзира на најизразитији прелом који је уочљив код 7. фактора, превладало је опредељење за избор 3 фактора према Гутман-Кајзеровом критеријуму који су остављени за даље тумачење резултата истраживања до којих се дошло факторском анализом с Варимакс ротацијом. 


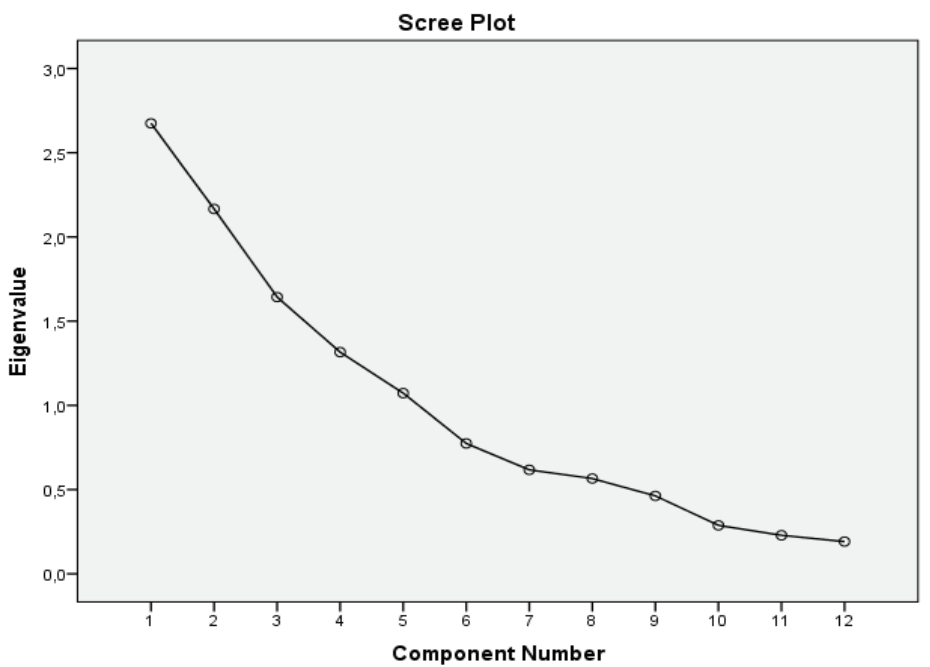

Дијаграм 1. Проиене студената о значају и потреби изучавања садржаја из комуникологије на студијама разредне наставе

Табела 4. Резултати факторске анализе с Варимакс ротацијом

\begin{tabular}{|c|c|c|c|}
\hline \multirow{2}{*}{ Ајтеми } & \multicolumn{3}{|c|}{ Компоненте } \\
\hline & I & II & III \\
\hline $\begin{array}{l}\text { a11 Комуникологија се значајно разликује од садржаја из } \\
\text { комуникологије у осталим научним областима. }\end{array}$ & 0,900 & & \\
\hline $\begin{array}{l}\text { a1 Пословно и лидерско комуницирање се разликује од садржаја из } \\
\text { комуникологије као посебне научне дисциплине. }\end{array}$ & 0,786 & & \\
\hline $\begin{array}{l}\text { а8 Облици изражавања у настави српског језика се разликују од } \\
\text { општих начела комуникологије. }\end{array}$ & 0,673 & & \\
\hline $\begin{array}{l}\text { а7 Садржаји из реторике се не поклапају са садржајима } \\
\text { комуникологије. }\end{array}$ & 0,664 & & \\
\hline а9 Комуникологија ми доприноси развоју опште говорне културе. & & 0,870 & \\
\hline $\begin{array}{l}\text { a15 Садржаји из комуникологије ми значајно доприносе стицању } \\
\text { комуникацијских компетенција. }\end{array}$ & & 0,848 & \\
\hline а10 Комуникологија ми доприноси развоју говорних вештина. & & 0,681 & \\
\hline $\begin{array}{l}\text { a13 Ефикасније бих решавао-ла проблеме у учењу ако би више учио-а } \\
\text { комуникологију. }\end{array}$ & & 0,338 & \\
\hline $\begin{array}{l}\text { а12 Комуникологија као научна дисциплина би требало да се учи на } \\
\text { студијама за разредну наставу. }\end{array}$ & & & 0,822 \\
\hline $\begin{array}{l}\text { a14 Нема превише садржаја из комуникологије у студијском програму } \\
\text { разредне наставе. }\end{array}$ & & & 0,662 \\
\hline $\begin{array}{l}\text { a6 Има мање значајних наставних предмета у студијском програму } \\
\text { разредне наставе од комуникологије. }\end{array}$ & & & 0,607 \\
\hline $\begin{array}{l}\text { а5 Учитељима би требало да се добро оспособе за интерперсоналну } \\
\text { комуникацију. }\end{array}$ & & & 0,589 \\
\hline
\end{tabular}

Подаци показују (Табела 4) да су према проценама студената издвојена три фактора која указују на потребу и значај учења наставних садржаја из комуникологије на факултетима на којима се образују будући учитељи. Први одређује чети- 
ри ајтема: 11, 1, 8 и 7; објашњава 21,740\% заједничке варијансе (Табела 3); назван је различитост садржаја. Други одређује четири ајтема: 9, 15, 10 и 13; објашњава 18,192\% заједничке варијансе (Табела 3); назван је значај учена. Трећи одређује 4 ајтема: 12, 4, 6 и 5; објашњава 14,099\% заједничке варијансе; назван је потреба учења.

Једнофакторском анализом варијансе истражен је утицај четири групе студената према уписаној години студија: 1 (прва), 2 (друга), 3 (трећа) и 4 (четврта) на њихове процене о значају и потреби учења садржаја из комуникологије на студијама за разредну наставу које су испитиване на Скалеру КНД-СРН.

Табела 5. Уписана година студија и проиене студената о значају и потреби учења комуникологије на студијама за разредну наставу

\begin{tabular}{cccccc}
\hline & Средњи скор & df & M & F & p \\
\hline Унутар групе & 48,980 & 3 & 16,327 & 0,905 & 0,441 \\
Између група & 1876,455 & 104 & 18,043 & & \\
Укупно: & 1925,435 & 107 & & & \\
\hline
\end{tabular}

Није утврђена статистички значајна разлика у резултатима четири групе студената према уписаној години студија о значају потреби учења комуникологије на студијама за разредну наставу: $\mathrm{F}(3 ; 104)=0,905 ; \mathrm{p}=0,441$ (Табела 5). Из наведеног разлога није рађено накнадно поређење помоћу Такојевог ХСД теста.

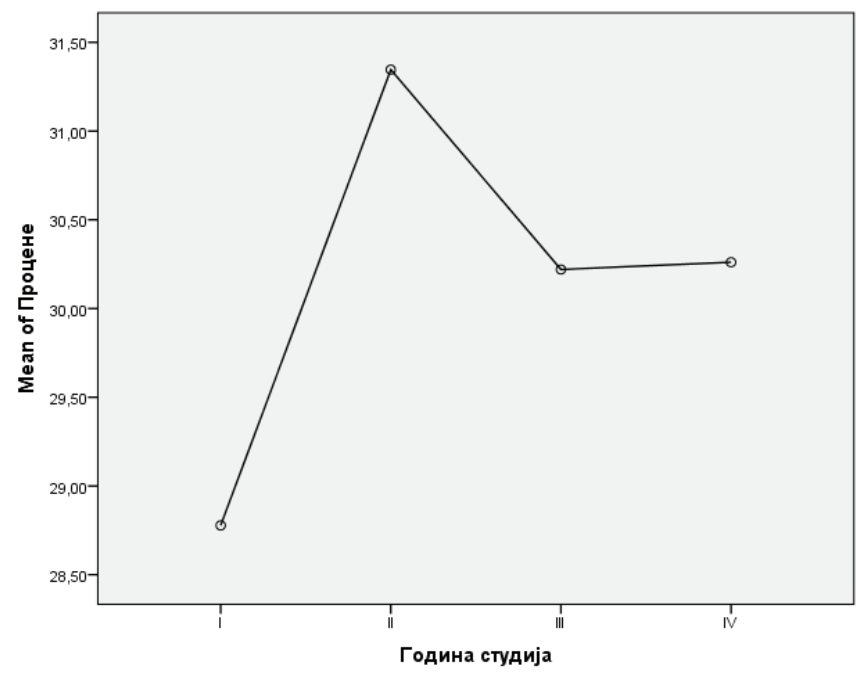

Дијаграм 2. Уписана година студија и проиене студената о значају и потреби учења комуникологије на студијама за разредну наставу (Scree Plot)

На Дијаграму 2 се види углавном уједначени пад изломљене линије која иде од студената друге године студија према студентима прве, као и треће и четврте године студија где је разлика готово неприметна, што додатно потврђује резултате истраживања на основу података ANOVE који су приказани у Табели 5. 


\section{Закључци и расправе}

У налазима теоријског проучавања у овом раду је утврђено да је комуникологија научна дисциплина значајна свим људима у свакодневном животу и деловању у различитим радним и друштвеним ситуацијама. Указано је и на значајан допринос комуникологије учитељима у обављању учитељске професије. Анализом студијских програма основних академских и мастер академских студија разредне наставе на факултетима у Републици Србији је утврђено да се она недовољно не изучава, па стога и будући учитељи немају довољно знања из ове области. За разлику од тога, у државама са развијенијим системима васпитања и образовања, комуникологија се на наставничким факултетима изучава у знатно већем обиму (Garcia Ramos et al, 2020; Golsan \& Rudick, 2018). Из наведеног разлога се истиче значај и потреба проучавања комуникологије као наставне дисциплине на студијама разредне наставе.

Детаљна анализа студијских програма за разредну наставу је показала да су на свим факултетима садржаји засновани на стицању знања, вештина и способности студената за обављање учитељске професије. Занемарује се једна друга страна припремања будућих учитеља, а то је њихово оспособљавање за ефикаснију комуникацију. На непотребно занемаривање комуникологије указују и нека истраживања спроведена у свету. У истраживању спроведеном 2020. у Сингапуру је утврђено да су на универзитетима Сингапура студије конципиране тако да студенти усвоје наставне садржаје који су повезани с њиховим дисциплинарним студијама, док се комуникацијске вештине углавном нуде кроз споредне течајеве током студија (Kathpalia et al, 2020: 227). Резултати овог истраживања су показали и да комуникацијске вештине студената, због недовољног изучавања комуникологије углавном зависе од њиховог укупног знања и комуникацијских вештина које поседују. На основу издвојених фактора на Скалеру КНД-СРН истраживања приказаног у овом раду се такође посредно може закључити да, без обзира што њиме нису испитиване комуникацијске вештине студената, зависе од општег знања и претходно стечених комуникацијских вештина студената.

Стални развој науке и технологије, посебно информатике, савремени проблеми комуницирања у настави настали услед глобалне пандемије, али и сталне промене у систему васпитања и образовања, условили су потребу ефикасније комуникације. Све то додатно указује и на значај комуникологије у ефикаснијем деловању будућих учитеља у школи и уопште у локалној и широј друштвеној заједници у којој живе. То потврђују и нека истраживања у којима су резултати показали да савремена дешавања у друштву и школи изискују потребу дефинисања не само циљева, него и облика и модела комуницирања у друштву и у школи (Baram Tsabari - Lewenstein, 2017). Овакави приступи указују на потребу научне комуникације, која подразумева оптимална знања из области комуникологије. Оно што може представљати проблем у комуникологији је у којој мери је она прилагођена потребама конкретног студијског програма, што је потврђено и 
у једном скоријем истраживању спроведеном у Аустралији, у коме су проучаване потребне вештине за ефикасну комуникацију у различитим областима (Mercer Mapstone - Kuchel, 2017). Све то важи и за студије разредне наставе, што отвара једно ново питање које би се у неким будућим истраживањима могло проучавати, а то је питање комуникацијских вештина и модела комуникације у разредној настави, што би свакако послужило и у креирању наставних садржаја из комуникологије на студијама за разредну наставу.

Анализом студијских програма за разредну наставу на основним и мастер академским студијама за разредну наставу у Републици Србији се може уочити да поред тога што се комуникологија недовољно изучава на студијама за разредну наставу и да постоји само мањи број тангентних наставних предмета, него се чак и они међусобно разликују и да поменуте наставне предмете углавном предају наставници из научних области језика и књижевности, психологије и социологије. То потврђује и први издвојени фактор различитост садржаја. Овакав тренд својствен је и осталим државама у свету, мада с одређеним посебним специфичностима (Webb \& Vaughn, 2019). Оне се првенствено огледају у зависности од сваког појединачног наставничког факултета и профила наставника који се на њему образују (Salamondra, 2021; Munz \& Colvin, 2018). На наставничким факултетима за образовање учитеља, углавном у европском и светском простору постоји сагласје о значају и потреби комуникологије на студијама за разредну наставу (Franks Thomas et al, 2020). На потребу усаглашености указује и Европски оквир о кључним компетенцијама просветних радника за рад у просвети и целоживотно учење (Миленовић, 2021; Миленовић, 2013).

У налазима емпиријског истраживања је најпре утврђено да су садржаји из комуникологије значајни за успешно обављање учитељске професије, што је у сагласју с налазима на основу критичких анализа изнетих у теоријском приступу проблему истраживања, што показују и издвојени фактори на Скалеру КНД-СРН, зато што су студенти разредне наставе обухваћени овим истраживањем високо вредновали ајтеме који указују на значај и на потребу учења комуникологије на студијама за разредну наставу. На то упућују и нека новија истраживања публикована у часописима водећих светских листа (Goodboy, 2018). Резултати овог спроведеног истраживања се у одређеној мери разликују од налаза неких од истраживања спроведених у свету у којима је, за разлику овог спроведеног истраживања, утврђен значај и потреба учења комуникологије на студијама за наставничка занимања, али у одређеним сферама, што се нарочито односи на интерперсоналну комуникацију у школи, и нарочито комуникацију између група деце у одељењу (Zahry \& Besley, 2021).

На основу резултата овог спроведеног истраживања се могу дати одређене педагошке импликације. Оне се пре свега односе на потребу продубљеније анализе истраживања овог проблема. Да за тим има потребе показали су и налази емпиријског истраживања. Истиче се и потреба учења темељних наставних садржаја из комуникологије који би с једне стране допринели стицању темељних знања од стране студената разредне наставе из комуникологије као науке, а са друге стране је реч о креирању наставних садржаја из комуникологије који 
би били непосредно повезани с потребама учитељске професије и потребама студената разредне наставе за обављање учитељске професије. Све то требало би бити за добробит студената разредне наставе и учитељске професије која је од националног значаја за сваку друштвену заједницу.

\section{Литература}

Balser, T., Grabau, A., Kniess, D. \& Page, L. (2017). Collaboration and Communication. New Directions for Institutional Research, 175(65), 65-79.

Baram Tsabari, A. \& Lewenstein, B. (2017). Science Communication Training: What Are We Trying to Teach? International Journal of Science Education, Part B: Communication and Public Engagement, 7(3), 285-300.

VanDerveer, B. \& Butterick, B. (2017). Championship Communication. Strategies: A Journal for Physical and Sport Educators, 30(6), 5-9.

Garcia Ramos, F., Zurian, F. \& Núñez Gómez, P. (2020). Gender Studies in Communication Degrees. Comunicar: Media Education Research Journal, 28(63), 21-30.

Golsan, K. \& Rudick, K. (2018). Critical Communication Pedagogy in/about/through the Communication Classroom. Journal of Communication Pedagogy,1(1), 16-19.

Goodboy, A. (2018). Instructional Communication Scholarship: Complementing Communication Pedagogy. Journal of Communication Pedagogy, 1(1), 9-11.

Zahry, N. \& Besley, J. (2021). University Attendance as Science Communication. International Journal of Science Education, Part B: Communication and Public Engagement, 11(2), 155-173.

Kathpalia, S., Ong, K. \& Leong, A. (2020). Communication Needs of Science Graduate Students. RELC Journal: A Journal of Language Teaching and Research, 51(2), 227-243.

Kohen, Z. \& Dori, Y. (2019). Toward Narrowing the Gap between Science Communication and Science Education Disciplines. Review of Education, 7(3), 525-566.

Ивковић, М. и Миленовић, Ж. (2014). Социјално-комуникацијске компетенције васпитача. Педагогија, 69(1), 61-70.

Јеленковић, П. и Јеленковић, љ. (2013). Системи комуникације у функцији избора професије - студија случаја Ниш. Теме, 37(2), 667-681.

Јеленковић, П. (2013). Историјски преглед развоја комуникологије. Пешчаник, 11(1), 226-239.

Kaufmann, R. \& Vallade, J. (2021). Online Student Perceptions of Their Communication Preparedness.

Mercer Mapstone, L. \& Kuchel, L. (2017). Core Skills for Effective Science Communication: A Teaching Resource for Undergraduate Science Education. International Journal of Science Education, Part B: Communication and Public Engagement, 7(2), 181-201.

Миленовић, Ж., Базић, Б. и Симић, М. (2014). Невербална комуникација у настави и свакодневном животу. Зборник радова Учитељског факултета у Ужииу, 17(16), 275-288. 
Миленовић, Ж. и Јефтовић, М. (2013). Социјално-комуникацијске компетеничје васпитача. У: П. Спасојевић (ур.) (2013). Зборник радова Савремено образовање и компетениије васпитача у предшколским установама са Прве стручно-научне конференције БАПТА, одржане у Станишићима, 2-3. 3. 2012. (29-47). Бијељина: Балкански савез удружења васпитача БАПТА из Београда.

Миленовић, Ж. (2021). Елементарна дидактика. Универзитет у Приштини - Косовској Митровици, Учитељски факултет.

Миленовић, Ж. (2013). Наставник у инклузивној настави. Београд: Задужбина Андрејевић.

Миленовић, Ж. (2010). Педагошко-психолошке компетенције наставника у инклузивној настави, рад са Првог конгреса педагога Републике Српске одржаног на Јахорини, 25-27.06.2009.. Наша школа, 16(1), 117-131.

Миленовић, Ж. (2009). Дидактичко-методичке компетенције наставника у инклузивној настави. У: Д. Боуиллет и М. Матијевић (ур.). Знанствена монографија Курикулуми раног одгоја и обвезног образовања са Треће међународне знанствене конференције, одржане у Задру, 13-15. 11. 2009. (493-506). Свеучилиште у Загребу, Учитељски факултет.

Мирков, Л. (2019). Приповедање у новинарству као жанровски поступак. СM: Communication and Media, 14(45), 135-156.

Munz, S. \& Colvin, J. (2018). Communication Apprehension: Understanding Communication Skills and Cultural Identity in the Basic Communication Course. Basic Communication Course Annual, 30(10), 172-199.

Salamondra, T. (2021). Effective Communication in Schools. BU Journal of Graduate Studies in Education, 13(1), 22-26.

Тривић, Н. (2019). Медији и комуникацијска р(еволуција). Политеа, 9(18), 115-135.

Ћитић, Т. (2020). Вештачка интелигенција у медијским интелигенцијама - радио и телевизија. Сочиолошки преглед, 1329-1345.

Franks Thomas, A., Comizio, R., Saint, J. \& Dockweiler, K. (2020). Strategic Communication for Advocacy. Communique, 49(21), 19-20.

Harel, D. \& McAllister, T. (2019). Multilevel Models for Communication Sciences and Disorders. Journal of Speech, Language, and Hearing Research, 62(4), 783-801.

Webb, N. \& Vaughn, M. (2019). Teaching the Communication Course: Intercultural Communication. Journal of Communication Pedagogy, 2(1), 53-57.

***Студијски план и програм дипломских мастер студија Учитељског факултета, Универзитета у Београду, 2015.

***Студијски програм за образовање учитеља Педагошког факултета у Врању, Универзитета у Нишу, 2015.

***Студијски програм ОАС4 - Дипломирани учитељ Учитељског факултета на мађарском наставном језику у Суботици, Универзитета у Новом Саду, 2014.

***Студијски програм за образовање учитеља Учитељског факултета, Универзитета у Београду, 2015.

***Студијски програм МAC1 - Мастер учитељ Учитељског факултета на мађарском наставном језику у Суботици, Универзитета у Новом Саду, 2014. 
***Студијски програм основних академских студија Мастер учитељ Педагошког факултета у Сомбору, Универзитета у Новом Саду, 2013.

***Студијски програм мастер академских студија за образовање учитеља Педагошког факултета у Врању, Универзитета у Нишу, 2015.

***Студијски програм мастер академских студија Разредна настава Учитељског факултета у Призрену - Лепосавићу, Универзитета у Приштини - Косовској Митровици, 2021.

***Студијски програм мастер академских студија Учитељ Педагошког факултета у Јагодини, Универзитета у Крагујевцу, 2021.

***Студијски програм основних академских студија Учитељ Педагошког факултета у Јагодини, Универзитета у Крагујевцу, 2021.

***Cтудијски програм: Мастер учитељ Педагошког факултета у Ужицу, Универзитета у Крагујевцу, 2019.

***Студијски програм основних академских студија Дипломирани учитељ Педагошког факултета у Сомбору, Универзитета у Новом Саду, 2013.

***Студијски програм основних академских студија Разредна настава Учитељског факултета у Призрену - Лепосавићу, Универзитета у Приштини - Косовској Митровици, 2021.

***Студијски програм: Учитељ Педагошког факултета у Ужицу, Универзитета у Крагујевцу, 2019.

\title{
COMMUNICATION SCIENCE AS A TEACHING DISCIPLINE IN THE STUDY PROGRAM FOR CLASSROOM TEACHING - NEED AND SIGNIFICANCE
}

\author{
Živorad Milenović \\ University of Pristina - Kosovska Mitrovica, Faculty of Teacher Education \\ Marija Milenović \\ University of Nis, Faculty of Philosophy, Department of Communication and \\ Journalism \\ Jelena Sedlarević \\ Elementary School in Smederevska Palanka
}

\begin{abstract}
The problem of research is the importance and need for learning communication as a teaching discipline in studies for classroom teaching, which is theoretically studied from the angle of university teaching, study of communication science and reflective practice of teachers and on an empirical level based on students' perception of classroom teaching. The research started from the general assumption that the contents from communication science are important for performing the teaching profession, but that it is insufficiently studied in the studies for class teaching. We also started from special assumptions that the research will single out the factors
\end{abstract}


that indicate the importance of learning content from communication studies in studies for primary education and that it will be determined that there is no significant difference in students' assessments of the importance and need for learning content from communication studies. For class teaching depending on the enrolled year of study. In order to determine that, in October 2021, on a sample of 108 students of the Study Program for Classroom Teaching at the Faculty of Teacher Education in Prizren - Leposavic, the research presented in this paper was conducted. Data collected by the CSTD-SCC Scalar $(\langle=.845)$ were processed by factor analysis and analysis of variance. Factor analysis singled out three factors: 1) the diversity of content, 2) the importance of learning and 3) the need to learn content from communication studies in the classroom. Analysis and analysis of variance showed that there is no significant difference in the assessments of primary school students about the importance and need to learn content from communication studies in primary school studies, depending on the enrolled year of study. He concludes that teaching contents in communication science are important for future teachers, that they are differently represented in study programs for classroom teaching in the Republic of Serbia, that students generally agree in assessments of the importance and need to learn communication science in classroom studies, which indicates the need to change and supplements of study programs for class teaching with teaching contents in communication science and the need for professional development of teachers in order to acquire the necessary knowledge in communication science.

Keywords: teaching profession, teacher, communication in the classroom, socialcommunication competencies, clear and loud expression, quality listening.

\section{Цитирање чланка:}

Миленовић, Ж., Миленовић, М. и Седларевић, Ј. (2021). Комуникологија као наставна дисциплина у студијском програму за разредну наставу - значај и потреба. Годишњак за педагогију, 6(2), 39-52. 